\title{
Disintegrating the Dullest Miracle on Earth? The Greek Crisis, Instrumentalism and European Identity
}

\author{
DAVID MICHAEL GREEN \\ Department of Political Science, Hofstra University, New York, Hempstead, \\ NY 11549, USA. Email: david.green@hofstra.edu
}

\begin{abstract}
The economic crisis in Greece, and the reaction to it by key European institutions, gives scholars a unique opportunity to test the instrumentalist model for explaining the dynamics of political identity. This study seeks to do that, marshalling both quantitative and qualitative indicators of European identity in Greece, and examining how this identity has changed over the past decade under conditions of crisis and external pressure. Do Greeks now self-identify less as European than they used to because the utility of such an identity has diminished? The evidence presented in this analysis suggests that that is the case.
\end{abstract}

\section{Introduction}

Social scientists are plagued by a major liability from which most physical scientists are free: we can rarely run experiments in order to test our theories and hypotheses. Sometimes, however, we can still get lucky, and a set of circumstances will arise that can be juxtaposed against measurement tools to allow a specific set of theoretical ideas to be tested. This study is built around just such a development.

Greece has experienced a harrowing near-decade of economic meltdown - perhaps the worst victim of the Great Recession (and its own corruption) in the West. This misery has been coupled with fraught negotiations and (at least perceived) draconian terms imposed by its rescuers, the 'Troika' - short for the International Monetary Fund, the European Central Bank, and the European Commission.

Meanwhile, during this period and well before, Eurobarometer and other surveys continued to ask questions about attitudes toward the European integration project, some of which were repeated in the same form both before and after the Crisis. (Of course, by most accounts the economic crisis in Greece is anything but over, with unemployment at $20.2 \%$ as of April 2018. In any case, for purposes of this study I use the terms 'after' or 'post-Crisis' to refer to the current relatively stable political 
situation.) Thus, this combination of developments and data allows us to explore answers to the question of what happens to identity under conditions in which one party experiences rejection from the very polity with which it is meant to identify. More specifically, we can add another test to the literature assessing the validity of instrumentalist approaches to the formation and maintenance of political identity.

Decades ago, Crawford Young enumerated three basic models for the study of identity in his essay, 'The dialectics of cultural pluralism: Concept and reality', one of which - along with primordialist and constructivist approaches - is instrumentalism. Young noted that this model - employed in studies by such scholars as Rothschild, ${ }^{1}$ Enloe, ${ }^{2}$ Young, ${ }^{3}$ Kasfir, ${ }^{4}$ Melson and Wolpe, ${ }^{5}$ Glazer and Moynihan, ${ }^{6}$ Olzak and Nagel, ${ }^{7}$ Bell, ${ }^{8}$ Saul, ${ }^{9}$ Nnoli, ${ }^{10}$ Bates, ${ }^{11}$ Rabushka and Shepsle ${ }^{12}$ and Hechter ${ }^{13}$ claimed that 'individuals had a repertory of social roles available for use in pursuit of material advantage'. Thus, he noted, identity 'becomes contingent, situational, and circumstantial', and the task for social scientists is therefore to 'identify the political factors which might activate it'. ${ }^{14}$

The condition of Greece at this time, and its relations with the rest of Europe offer a chance to do just that. The goal of this study is to take advantage of the combination of historical circumstances that have defined the relationship between Greece and Europe in recent years and the existence of longitudinal quantitative measures of identity in Greece, in order to test the validity of instrumentalist models of political identity. In other words, what happened to the sense of European identity among Greeks under conditions in which the tangible, instrumental, benefits of being part of Europe were perceived to diminish?

\section{The Context and the Stakes}

Like much of the rest of the Western world (and beyond), the Greek economy went into a tailspin in 2008. This Great Recession was the worst since the Great Depression of the 1930s. All countries were hit badly, but in Greece conditions were especially onerous, for several reasons. To begin with, the Greek economy had always been among the weakest in Europe. Wedging Greece into the newly created club of Eurozone members at the turn of the century, for example, was not only an act of political will rather than a matter of meeting the specifically defined economic criteria, it was also, in fact, a demonstration of political will used to subvert those very criteria.

Greece's ongoing condition, combined with its traditions of corruption, legal and otherwise, and employment heavily driven by patronage practices, put it in a particularly vulnerable and precarious position relative to other European Union member-states - arguably the worst within the Eurozone club as the Crisis began. Then things rapidly got worse. As 2009 came to a close, the government revealed that its deficit - at $12.7 \%$ of GDP - was more than twice what it had been claiming previously. More upward revisions would then follow, until a year later the EU estimated that Greece's 2009 ratio was actually 15.4\%, (barely) second only to Iceland. 
On top of this - and to add insult to injury from the perspective of the country's European partners - it was revealed that part of the explanation for why the real figures were so much higher than those reported was because of intentional deceit. The Greek government had been colluding with Wall Street banks to find ways of borrowing money off the books in terms of the Maastricht rules governing permissible amounts of debt for Eurozone members (in fairness, Greece was not alone among member-states using this practice). These conditions and revelations produced a crisis with respect to the government's ability to service its debt and required the 'Troika' to mount a financial rescue, which it did in 2010, and then again in 2012 and 2015.

In each case, these bailouts were conditioned on rather severe domestic austerity requirements for Greece. This, of course, produced considerable pain and political turmoil at home, including changeovers of governments, new elections, a high-profile referendum, rising and falling parties, etc. More to the point for purposes of this study, however, it also produced a resentment among some Greeks toward their European partners, who were seen as kicking a fellow family member who was already down and, worse, even 'othering' Greece to the point that it was no longer thought of as family at all.

Why does this matter, other than to Greeks who are suffering economically still to this day? One answer to that question is that it matters to the extent that the European integration project matters, and that that project matters not least for the reasons cited by columnist Roger Cohen:

A near borderless Europe at peace constitutes the great achievement of the second half of the 20th century. That you can go from Germany to Poland across a frontier near effaced and scarcely imagine the millions slaughtered seven decades ago is testament to the accomplishment. The European Union is the dullest miracle on earth. ${ }^{15}$

If the EU is thus worth preserving, and if one accepts as axiomatic the notion that institution building in the absence of identity building is the political equivalent of constructing a skyscraper on a foundation of sand, the question matters, and all the more so if one assumes that instrumentalism is at least part of the identity formation and maintenance equation. In other words, what happens to Europe when the winds blow ill, if at that time no one feels themselves to be European?

This question is premised on a notion that is hardly a new idea. As Easton and Dennis long ago noted, polities are dependent upon a level of 'diffuse support [which] forms a reservoir upon which a system typically draws in times of crises, such as depressions, wars, and internecine conflicts, when perceived benefits may recede to their lowest ebb'. ${ }^{16}$ In short, for those who think that the post-Second World War project of European integration is worth preserving, the question of identity is worth exploring. Because, if the above-referenced scholars are correct, one cannot expect the former to persevere in the absence of the latter. That is: no identification, no (lasting) integration. And thus, what has happened to European identity in Greece over the last decade is consequential, and is therefore the focus of this study. 


\section{The State of the Art: Research on European Identity}

At least since the advent of Eurobarometer in the early 1970s, empirical data on the question of identity in Europe have been available to scholars who have, for most of that period, been examining it for clues to understanding the hearts and minds of Europeans. One of the earliest findings was the apparent correlation of popular national attitudes on Europe to the date of entry. ${ }^{17}$ The greater level of support among the longer-term members was not always present, and was probably instrumentally-driven, Inglehart argued, with the perceived benefits of EC membership producing the stronger sense of supranational identity in these countries.

Another noteworthy study of the phenomenon was crafted by Duchesne and Frognier, who addressed the question posed by their title, 'Is there a European identity?'. ${ }^{18}$ The answer they found was affirmative, but only marginally so: between 1 and $9 \%$ of respondents in the polled countries selected Europe as their first identity choice, with between 6 and 26\% selecting it either first or second (195). In The Europeans, ${ }^{19}$ Green employed a wider range of questions measuring the extent of European identity, and determined that roughly $15 \%$ of Europeans strongly identified as such, while another $35 \%$ also did but less strongly.

Building on the general foundations established by these broader explorations of the phenomenon, the past decade has witnessed the exploration of more particular questions related to European identity. The examples abound - including work by Schilde, ${ }^{20}$ Agirdag et al., ${ }^{21}$ Quintelier et al. ${ }^{22}$ Fligstein et al., ${ }^{23}$ Mitchell, ${ }^{24}$ Gnutzmann et al. ${ }^{25}$ Roose, ${ }^{26}$ Green, ${ }^{27} \mathrm{Cram}^{28}$ and Hadler et al. ${ }^{29}$ These studies examine the phenomenon from the perspective of various specific causal relationships, though instrumentalist approaches are not generally considered.

Finally, and particularly relevant to the current analysis, several recent studies have examined the phenomenon in the context of the current economic crisis, including those by Risse, ${ }^{30}$ Chalániová ${ }^{31}$ and Visvizi. ${ }^{32}$

\section{Methods and Sources}

In order to address the core question posed by this study, I have drawn on two sources, one quantitative and one qualitative. The primary emphasis of the study is on analysing indicators of broad public sentiment, particularly in Greece. Towards that end, I have examined an extensive volume of survey data sets ranging over the past five decades, looking for measures of European identity. Of particular interest were any that allowed for a longitudinal analysis, and any that incorporated demographic and other valuable measures of public sentiment that could be juxtaposed against identity measures. I reviewed every Eurobarometer, International Social Survey Programme (ISSP), World Values Survey (WVS), European Values Survey (EVS), and European Community Studies (ECS) survey fielded from 1970 to the present, looking for those that included such measures. In the end, a number of Eurobarometer and a couple of ISSP surveys were found to possess the data required for the current analysis. 
Real measures of European identity show up in four basic formats within the universe of European public opinion surveys (see Ref. 19, for the original classification of these survey questions into respective format categories). Unfortunately, only Format Four questions - asking respondents how attached they feel to Europe, with four response choices, from 'not at all attached' to 'very attached' - appear in both the pre- and post-Crisis periods, and they are thus examined in this study. Statistical techniques employed include simple means and cross-tabular juxtapositions, permitting initial empirical responses to the questions at the heart of this study.

In addition to these quantitative data, in June 2016 I interviewed about a dozen individuals in Greece to ascertain their sense of the public's attitudes toward Europe. Most of these informants were located in Athens, and most held professional positions (e.g. businessmen, academics). However, other interviews were conducted with non-professionals as well, and in various other parts of the country. The purpose of these interviews was to add another dimension to the investigation of the present question, allowing a multi-methodological triangulation on the findings, and limiting the liabilities inherent upon reliance on survey instruments alone, as well as to observe first-hand the nature and character of the European Union's presence in Greece.

\section{Findings}

The Format Four identity question was fielded across twelve Eurobarometer and ISSP surveys, ranging from October 1991 to November 2015. Those from prior the Crisis include Eurobarometers ${ }^{33} 36.0$ (10/91), 51.0 (3/99), 54.1 (11/00), 60.1 (10/03), $62.0(10 / 04), 63.4(5 / 05), 65.2(3 / 06)$ and $67.1(2 / 07)$, along with ISSP ${ }^{34}$ surveys from 1995 and 2003. From the post-Crisis period, Eurobarometers 82.3 (11/14) and 84.3 (11/15) are included. (Additional Eurobarometer surveys are also included for a brief comparative measure of attachment to the European Union. See Table 1B.)

The question utilized herein as a measure of European identity is typically part of a series of questions posed to respondents in these surveys, asking 'Please tell me how attached you feel to...?' Usually, there is a separate question for the locality, the country, the European Union, and for Europe. For each of these prompts, respondents may choose between 'Very attached', 'Fairly attached', 'Not very attached' and 'Not at all attached'.

For this study, I used the 'attached to Europe' question to measure European identification, although I have also reported the 'attached to the European Union' responses for purposes of validity confirmation, and because the differences between the two responses are instructive with regard to attitudes in Europe.

Table 1 summarizes the responses to these two questions from the surveys examined, disaggregated by country, and then recombined in several appropriate groupings. For each entry in the table, I have combined the 'Very attached' and 'Fairly attached' percentages into a single figure measuring the existence of some significant amount of identification with Europe.

The EU versus Europe identity distinction can be seen in the summary statistics of Table 1 (these summary figures are averages of percentages, and are not weighted 
Table 1A. Attachment to Europe. (Percent choosing 'Very' and 'Fairly Attached')

\begin{tabular}{|c|c|c|c|c|c|c|c|c|c|c|c|c|c|c|}
\hline \multirow[b]{3}{*}{ Member-State / Category } & \multirow{2}{*}{$\frac{\text { EB } 36.0}{10 / 91}$} & \multirow{2}{*}{$\frac{\text { ISSP }}{1995}$} & \multirow{2}{*}{$\frac{\text { EB-51.0 }}{3 / 99}$} & \multirow{2}{*}{$\frac{\text { EB-54.1 }}{11 / 00}$} & \multirow{2}{*}{$\frac{\text { EB } 60.1}{10 / 03}$} & \multirow{2}{*}{$\frac{\text { ISSP }}{2003}$} & \multirow{2}{*}{$\frac{\text { EB } 62.0}{10 / 04}$} & \multirow{2}{*}{$\frac{\text { EB } 63.4}{5 / 05}$} & \multirow{2}{*}{$\frac{\text { EB } 65.2}{3 / 06}$} & \multirow{2}{*}{$\frac{\text { EB } 67.1}{2 / 07}$} & \multirow{2}{*}{$\frac{\text { EB } 82.3}{11 / 14}$} & \multirow{2}{*}{$\frac{\text { EB } 84.3}{11 / 15}$} & \multirow[b]{2}{*}{ Pre-crisis } & \multirow[b]{2}{*}{ All surveys } \\
\hline & & & & & & & & & & & & & & \\
\hline & Total & Total & Total & Total & Total & Total & Total & Total & Total & Total & Total & Total & mean & Mean \\
\hline Belgium & 50.6 & & 64.3 & 64.6 & 67.2 & & 73.4 & 72.9 & 71.2 & 73.4 & 57.2 & 62.5 & 67.2 & 65.7 \\
\hline Denmark & 61.7 & & 71.7 & 68.2 & 70.0 & 53.9 & 75.8 & 75.6 & 68.6 & 81.3 & 71.4 & 74.7 & 69.6 & 70.3 \\
\hline Germany & 49.0 & 58.6 & 60.2 & 60.5 & 63.9 & 59.9 & 69.1 & 65.9 & 67.8 & 71.5 & 64.6 & 67.4 & 62.6 & 63.2 \\
\hline Greece & 53.6 & & 42.7 & 44.6 & 52.6 & & 48.8 & 46.5 & 43.8 & 48.0 & 39.3 & 39.9 & 47.6 & 46.0 \\
\hline Spain & 56.1 & 62.3 & 70.5 & 72.9 & 68.6 & 77.9 & 69.5 & 65.4 & 60.3 & 70.3 & 49.2 & 60.4 & 67.4 & 65.3 \\
\hline France & 55.2 & & 55.3 & 58.7 & 58.4 & 54.5 & 67.4 & 64.7 & 58.8 & 63.2 & 59.5 & 60.8 & 59.6 & 59.7 \\
\hline Ireland & 36.0 & 44.4 & 55.5 & 54.8 & 56.8 & 44.4 & 70.6 & 68.7 & 66.4 & 65.7 & 47.2 & 55.5 & 56.3 & 55.5 \\
\hline Italy & 66.1 & 68.4 & 67.9 & 68.9 & 68.9 & & 77.0 & 76.4 & 71.2 & 70.2 & 47.2 & 45.6 & 70.6 & 66.2 \\
\hline Luxembourg & 57.3 & & 81.3 & 68.8 & 64.7 & & 80.0 & 86.7 & 77.7 & 75.0 & 71.4 & 81.5 & 73.9 & 74.4 \\
\hline Netherlands & 32.1 & 54.3 & 51.2 & 55.8 & 31.6 & 47.0 & 60.9 & 57.9 & 53.1 & 58.7 & 55.4 & 60.4 & 50.3 & 51.5 \\
\hline $\begin{array}{l}\text { Portugal } \\
\text { Pal }\end{array}$ & 43.5 & & 62.7 & 63.9 & 66.0 & 67.9 & 61.5 & 57.1 & 61.2 & 66.0 & 47.9 & 53.7 & 61.1 & 59.2 \\
\hline United Kingdom & 37.7 & 21.9 & 39.1 & 42.6 & 42.4 & 27.2 & 50.7 & 48.8 & 47.2 & 52.4 & 42.1 & 49.7 & 41.0 & 41.8 \\
\hline Austria & & 68.4 & 64.8 & 66.3 & 68.1 & 70.9 & 63.0 & $\begin{array}{l}6.0 \\
66.7\end{array}$ & 60.7 & 60.6 & 57.2 & 55.6 & 65.5 & $\begin{array}{l}1.0 \\
63.8\end{array}$ \\
\hline Sweden & & 38.5 & 73.2 & 76.3 & 74.1 & 48.8 & 77.8 & 79.6 & 77.9 & 78.3 & 76.0 & 76.6 & 69.4 & 70.6 \\
\hline Finland & & & 66.8 & 66.7 & 63.8 & 39.6 & 72.7 & 74.6 & 68.7 & 71.8 & 69.3 & 64.9 & 65.6 & 65.9 \\
\hline Cyprus & & & & & & & 48.9 & 36.8 & 30.0 & 48.0 & 26.9 & 28.0 & 40.9 & 36.4 \\
\hline Czech Republic & & 78.5 & & & & 71.8 & 79.1 & 76.3 & 74.6 & 73.8 & 56.8 & 56.9 & 75.7 & 71.0 \\
\hline Estonia & & & & & & & 44.8 & 54.2 & 47.0 & 53.2 & 55.1 & 52.9 & 49.8 & 51.2 \\
\hline $\begin{array}{l}\text { Hungary } \\
\text { Hung }\end{array}$ & & 94.2 & & & & 93.7 & 91.1 & 91.7 & 82.9 & 88.2 & 68.7 & 75.0 & 90.3 & 85.7 \\
\hline $\begin{array}{l}\text { Latvia } \\
\text { la }\end{array}$ & & 36.1 & & & & 19.6 & 56.9 & 57.7 & 49.0 & 56.1 & 59.8 & 67.4 & 45.9 & 50.3 \\
\hline Lithuania & & & & & & & 47.6 & 46.5 & 44.0 & 49.0 & 52.5 & 53.8 & 46.8 & 48.9 \\
\hline Malta & & & & & & & 58.3 & 61.9 & 60.0 & 76.0 & 61.8 & 68.2 & $\begin{array}{l}+0.0 \\
64.1\end{array}$ & 64.4 \\
\hline Poland & & 69.5 & & & & 63.0 & 86.0 & 85.6 & 86.3 & 82.6 & 66.1 & 65.6 & 78.8 & 75.6 \\
\hline Slovakia & & 81.4 & & & & 69.5 & 69.5 & 70.2 & 60.8 & 65.8 & 62.8 & 62.2 & 69.5 & 67.8 \\
\hline Slovenia & & 69.3 & & & & 66.7 & 79.9 & 74.6 & 63.8 & 67.8 & 45.4 & 56.7 & 70.4 & 65.5 \\
\hline Bulgaria & & 86.7 & & & & 72.5 & & & 0.0 & 66.7 & 51.7 & 55.5 & 56.5 & 55.5 \\
\hline Romania & & & & & & & & & 0.0 & 70.7 & 63.2 & 63.8 & 35.4 & 49.4 \\
\hline Croatia & & & & & & & & & 0.0 & 0.0 & 49.1 & 57.8 & $\begin{array}{r}3.4 \\
0.0\end{array}$ & 26.7 \\
\hline Other & & & & & & & & & 0.0 & 0.0 & 58.7 & 30.8 & 0.0 & 22.4 \\
\hline All countries & 50.8 & 61.9 & 58.6 & 60.4 & 59.8 & 58.5 & 68.8 & 67.1 & 64.3 & 67.7 & 55.9 & 55.6 & 61.8 & 60.8 \\
\hline EB-15 only * & 49.9 & & 61.8 & 62.2 & 61.1 & & $\begin{array}{l}0.0 \\
67.9\end{array}$ & 67.2 & 63.6 & 67.1 & 57.0 & 60.6 & $\begin{array}{l}02.6 \\
62.6\end{array}$ & $\begin{array}{l}61.8 \\
61.8\end{array}$ \\
\hline Hard times states only & 47.3 & & $\begin{array}{l}0.0 \\
57.9\end{array}$ & $\begin{array}{l}02.2 \\
59.1\end{array}$ & 61.0 & & 62.6 & 59.4 & $\begin{array}{l}03.0 \\
57.9\end{array}$ & $\begin{array}{l}0.1 \\
62.5\end{array}$ & $\begin{array}{l}35.0 \\
45.9\end{array}$ & $\begin{array}{l}00.0 \\
52.4\end{array}$ & $\begin{array}{l}0.0 \\
58.5\end{array}$ & $\begin{array}{l}0.0 \\
56.6\end{array}$ \\
\hline $\begin{array}{l}\text { Pro-austerity states only } \\
\text { (GE, NE, FI) *** }\end{array}$ & 40.6 & & 59.4 & 61.0 & 53.1 & & 67.6 & 66.1 & 63.2 & 67.3 & 63.1 & 64.2 & 59.8 & 60.6 \\
\hline$N^{(O L, N E, T I)}$ & 11928 & 17478 & 15225 & 15322 & 15744 & 20961 & 24330 & 24305 & 12235 & 26417 & 27902 & 28714 & & \\
\hline
\end{tabular}

*These are simple averages of country data shown, and thus are unweighted** Finland not included in figure for EB-36.0 (1991) Survey 
Table 1B. Attachment to European Union.(Percent choosing 'Very' and 'Fairly Attached')

\begin{tabular}{|c|c|c|c|c|c|c|c|c|c|c|c|}
\hline \multirow[b]{3}{*}{ Member-state / category } & \multirow{3}{*}{$\frac{\text { EB 58.1 }}{\frac{10 / 02}{\text { Total }}}$} & \multirow{3}{*}{$\frac{\text { EB } 65.2}{3 / 06} \frac{}{\text { Total }}$} & \multirow{3}{*}{$\frac{\text { EB 67.2 }}{\frac{4 / 07}{\text { Total }}}$} & \multirow{3}{*}{$\frac{\text { EB } 68.1}{\frac{9 / 07}{\text { Total }}}$} & \multirow{3}{*}{$\frac{\text { EB 73.3 }}{\frac{3 / 10}{\text { Total }}}$} & \multirow{3}{*}{$\frac{\text { EB 79.5 }}{\frac{6 / 13}{\text { Total }}}$} & \multirow{3}{*}{$\frac{\frac{\text { EB } 80.1}{11 / 13}}{\text { Total }}$} & \multirow{3}{*}{$\frac{\frac{\text { EB } 82.3}{11 / 14}}{\text { Total }}$} & \multirow{3}{*}{$\frac{\frac{\text { EB } 84.3}{11 / 15}}{\text { Total }}$} & \multirow[b]{3}{*}{ Mean } & \multirow[b]{3}{*}{$\begin{array}{l}\text { Attachment to } \\
\text { Europe - to the EU }\end{array}$} \\
\hline & & & & & & & & & & & \\
\hline & & & & & & & & & & & \\
\hline Belgium & 50.2 & 60.5 & 66.7 & 65.4 & 50.6 & 61.3 & 57.9 & 50.9 & 55.8 & 57.7 & 8.0 \\
\hline Denmark & 44.8 & 50.7 & 44.2 & 44.4 & 40.3 & 43.3 & 44.9 & 44.1 & 46.5 & 44.8 & 25.5 \\
\hline Germany & 48.0 & 49.5 & 55.4 & 53.2 & 55.5 & 56.3 & 54.4 & 49.0 & 53.7 & 52.8 & 10.4 \\
\hline Greece & 38.5 & 38.4 & 40.4 & 39.3 & 44.5 & 29.4 & 29.2 & 32.7 & 34.2 & 36.3 & 9.7 \\
\hline Spain & 44.4 & 56.5 & 62.7 & 54.8 & 61.5 & 43.3 & 47.6 & 45.0 & 55.7 & 52.4 & 12.9 \\
\hline France & 54.0 & 53.3 & 56.5 & 58.0 & 56.2 & 53.8 & 49.0 & 51.6 & 54.8 & 54.1 & 5.5 \\
\hline Ireland & 50.9 & 54.0 & 55.6 & 44.7 & 51.6 & 46.8 & 41.3 & 41.2 & 50.7 & 48.5 & 7.0 \\
\hline Italy & 63.0 & 67.0 & 65.0 & 59.1 & 74.4 & 51.0 & 44.2 & 38.9 & 40.4 & 55.9 & 10.3 \\
\hline Luxembourg & 64.7 & 50.0 & 65.0 & 60.0 & 60.8 & 66.7 & 61.1 & 66.6 & 76.9 & 63.5 & 10.9 \\
\hline Netherlands & 29.7 & 31.8 & 33.1 & 31.6 & 33.3 & 35.6 & 35.1 & 33.1 & 38.8 & 33.6 & 18.0 \\
\hline Portugal & 50.4 & 50.4 & 58.9 & 55.2 & 56.4 & 41.5 & 42.9 & 47.4 & 53.1 & 50.7 & 8.5 \\
\hline United Kingdom & 29.0 & 38.6 & 35.1 & 26.7 & 27.6 & 30.7 & 27.6 & 32.1 & 40.0 & 31.9 & 9.9 \\
\hline Austria & 49.1 & 49.8 & 48.7 & 40.8 & 53.9 & 45.7 & 44.7 & 40.4 & 38.2 & 45.7 & 18.1 \\
\hline Sweden & 34.7 & 39.7 & 39.6 & 44.0 & 36.5 & 45.2 & 36.4 & 40.5 & 44.0 & 40.1 & 30.6 \\
\hline Finland & 25.0 & 31.8 & 32.2 & 27.9 & 35.3 & 35.5 & 36.9 & 35.6 & 39.1 & 33.3 & 32.6 \\
\hline Cyprus & & 31.6 & 36.6 & 27.5 & 38.8 & 35.2 & 26.8 & 28.8 & 25.0 & 31.3 & 5.1 \\
\hline Czech Republic & & 49.3 & 52.0 & 41.5 & 41.5 & 35.2 & 35.8 & 36.8 & 34.5 & 40.8 & 30.2 \\
\hline Estonia & & 29.6 & 41.4 & 34.9 & 35.8 & 46.1 & 45.7 & 50.6 & 47.8 & 41.5 & 9.7 \\
\hline Hungary & & 64.5 & 62.1 & 51.0 & 59.8 & 49.1 & 54.4 & 51.6 & 59.1 & 56.5 & 29.2 \\
\hline Latvia & & 46.7 & 55.0 & 43.4 & 49.5 & 55.1 & 56.7 & 56.3 & 65.0 & 53.5 & -3.1 \\
\hline Lithuania & & 42.9 & 43.2 & 36.2 & 38.4 & 48.4 & 39.1 & 46.7 & 51.4 & 43.3 & 5.6 \\
\hline Malta & & 45.5 & 60.0 & 50.0 & 52.4 & 54.2 & 43.5 & 48.6 & 60.0 & 51.8 & 12.6 \\
\hline Poland & & 62.7 & 68.1 & 66.4 & 67.5 & 59.8 & 58.1 & 61.0 & 58.4 & 62.8 & 12.8 \\
\hline Slovakia & & 43.9 & 56.4 & 43.8 & 64.2 & 55.6 & 51.9 & 53.9 & 49.3 & 52.4 & 15.4 \\
\hline Slovenia & & 62.3 & 56.0 & 52.9 & 47.1 & 40.0 & 41.4 & 39.2 & 50.0 & 48.6 & 16.9 \\
\hline Bulgaria & & 0.0 & 45.5 & 45.3 & 58.3 & 57.4 & 53.5 & 43.5 & 44.3 & 43.5 & 12.0 \\
\hline Romania & & 0.0 & 65.9 & 62.9 & 53.8 & 51.3 & 50.1 & 58.4 & 60.2 & 50.3 & -0.9 \\
\hline Croatia & & 0.0 & 0.0 & 0.0 & 0.0 & 46.2 & 47.5 & 40.1 & 54.5 & 23.5 & 3.2 \\
\hline Other & & 0.0 & 0.0 & 0.0 & 67.8 & 57.4 & 49.9 & 52.6 & 32.0 & 32.5 & -10.1 \\
\hline All countries & 46.6 & 51.9 & 54.4 & 50.6 & 53.8 & 47.8 & 45.6 & 45.3 & 47.2 & 49.2 & 11.5 \\
\hline EB-15 only $*$ & 45.1 & 48.1 & 50.6 & 47.0 & 49.2 & 45.7 & 43.5 & 43.3 & 48.1 & 46.8 & 15.1 \\
\hline $\begin{array}{l}\text { Hard times states only } \\
\text { (GR, PO, SP, IR) * }\end{array}$ & 46.1 & 49.8 & 54.4 & 48.5 & 53.5 & 40.3 & 40.3 & 41.6 & 48.4 & 47.0 & 9.6 \\
\hline $\begin{array}{l}\text { Pro-austerity states only } \\
\text { (GE, NE, FI) } * * *\end{array}$ & 34.2 & 37.7 & 40.2 & 37.6 & 41.4 & 42.5 & 42.1 & 39.2 & 43.9 & 39.9 & 20.7 \\
\hline$N$ & 15630 & 11798 & 24044 & 25950 & 26054 & 27626 & 25450 & 27902 & 28714 & & \\
\hline
\end{tabular}

*These are simple averages of country data shown, and thus are unweighted 
according to number of respondents for each country in each survey). The last of the Table 1A columns presents mean European attachment values across all the reported surveys. Similarly, the penultimate column for Table 1B does the same for EU attachment. Lastly, the final column in Table 1B subtracts the latter from the former, providing a net difference in long-term national attitudes between the two. In Belgium, for example, the mean attachment level (that is, the combination of those very and fairly attached) to Europe across all the relevant surveys was $65.7 \%$, while to the EU it was $57.7 \%$. Thus, the last column reports that about $8.0 \%$ more Belgians tend to be attached to Europe than to the EU, factoring in all surveys across the quarter-century covered by the data. As it happens, Belgium is not unusual in this respect, as the attachment difference value for all countries in the study is $11.5 \%$, favouring Europe over the EU.

The core question this study addresses is whether the events surrounding the Great Recession - and, in particular, Greece's fiscal meltdown and the EU/Troika's austerity-based response to it - have affected levels of European identification. As a starting place for observing any impact empirically, a longitudinal analysis is critical. A hypothesis fitting within the instrumentalist approach to political identity would suggest that, at least for some Europeans, levels of European identification have diminished from pre-Crisis norms.

Looking first at the figures for all countries in the surveys, Table 1A shows that the pre-Crisis (that is, including all surveys - 1991-2007 - except the most recent two from 2014 and 2015) mean the identification with Europe value was 61.8\%. Moreover, in the last series of surveys on the eve of the Great Recession (2004, 2005, 2006 and 2007), the figures were substantially higher still, ranging from 64.3 to $68.8 \%$. The drop-off to the post-Crisis figures of 55.9\% (2014) and 55.6\% (2015) are thus fairly noteworthy.

In addition, if we look at the changes over time in two groups of member-states presumably representing polar positions on how the EU should have reacted to the Crisis, we can see some further support for the hypothesized developments. For the four countries included in the 'hard-times' cohort, European identification levels were $58.5 \%$ for all surveys prior to the recession, and slightly higher than that in the years directly preceding it (2004-2007). In the two surveys from 2014 and 2015, the collective identity levels had dropped to 45.9 and $52.4 \%$, respectively. These were the countries who could - fairly or not - make something of a grievance claim against their fellow Europeans, the EU and related institutions for kicking them with austerity demands at the moment of their greatest need. The data are thus supportive of the notion - again, leaving aside proof of causality issues - that the policies in question, and the perceptions of those policies, produced a substantial alienation from Europe for Greeks, Portuguese, Spaniards and the Irish - to the tune of a loss of something like one-fourth of the previous count of European identifiers (that is, from roughly $60 \%$ in the years just prior to the Recession to $45.9 \%$ in 2014 ), albeit with a partial recovery in 2015.

Meanwhile, the opposite movement occurred among the 'winners' of this policy dispute. That is - and despite the overall trend noted above in which levels for all 
countries in the surveys were collectively falling - European identification actually rose among the 'pro-austerity' countries that got their way as the Crisis unfolded. Within these three countries, European identifiers amounted to $59.8 \%$ of the population across all pre-Crisis surveys, albeit rising to perhaps 65 or $66 \%$ in the four years prior to the Recession. These figures are all more or less identical to the trends for the total of all countries in the surveys. However, the post-Crisis figures represent a significant departure. For all countries in the surveys, the drop from the pre-Crisis allsurvey mean to the 2014 figure is about six percentage points (or a loss of about onetenth of the identifier cohort), from 61.8 to $55.9 \%$. And for the 'hard-times' group the loss was even greater, from 58.5 to $45.9 \%$. But the pro-austerity countries actually saw moderate growth in European identification at the same time others were going the other way. For these three countries, the $59.8 \%$ average for the pre-Crisis surveys becomes $63.1 \%$ by 2014 , growing further to $64.2 \%$ in 2015 . This is especially true for the Netherlands, which rises from $50.3 \%$ prior to the Crisis to $55.4 \%$ and $60.4 \%$ after. All of these figures fit with the instrumentalist approach to identity, as those who are getting what they want from the polity are growing in identification, while those being stiff-armed are falling on the same measure.

Finally, we turn specifically to Greece, the core focus of this study, which gives us a natural laboratory to test instrumentalist theories of identity. Identity levels did indeed drop in Greece, as Table 1A shows. Prior to the Crisis, the average portion of surveyed Greeks identifying with Europe was $47.6 \%$, which is also about what it was in the subset of that group of surveys covering the four years (2004-2007) just prior to the Recession hitting. In 2014 and 2015, on the other hand, the number had fallen to just over $39 \%$, a substantial drop. Compared with its pre-Crisis average of $47.6 \%$ identifying with Europe, the $39.3 \%$ in 2014 was a loss of almost one-fifth of European identifiers. That's almost double the loss for all countries in the surveys, but - interestingly - not as big a proportion leaving the identifier camp as in Spain (a little more than a fourth) or Portugal (a little less than a fourth).

So Greece offers something of a complicated answer to the question. On the one hand, European identity acts as we might expect it would if instrumentalist theories of identity are valid, with levels falling as Europe offered Greece tough terms in exchange for assistance. (Additionally, the figures for the pro-austerity countries are further validation, since people in those countries were getting what they - or at least their governments - wanted from these institutions, and their levels of identity rose at the same time.) On the other hand, European identity among Greeks takes less of a hit during the Crisis than it does among Spaniards or the Portuguese, who also went through economic crises and were subjected to imposed austerity programmes though less severe, less protracted, less overt, and less politically contentious than in Greece.

It's worth noting that European identity levels in Greece weren't terribly high to start with, arguably meaning that there were fewer marginal identifiers than in other countries, waiting to be dislodged by an ill wind of one sort or another. As Table 1A reveals, the average of $47.6 \%$ of Greeks identifying with Europe across the pre-Crisis surveys is the lowest among surveyed countries, with the exception of Britain and a 
small handful of relatively peripheral and recently acceding member-states. Still, identification with Europe did fall after the Crisis and the Troika's response, as predicted, though perhaps not as much as one might have expected lacking deeper analysis of the situation.

Here, the qualitative fieldwork informing this study may help in explaining why Greek levels of European identification did not drop further than they did, for these interviews reveal some potential mitigating factors to anti-European hostility. One such factor is the widespread understanding in Greece that - however villainous one perceives the Troika to have been - Greece itself is not without blame for the stringsladen aid Europe offered after Greece's implosion. It's well understood in Greece that the government was for years profligate in spending and therefore reckless in maintaining order within its fiscal house. Thus, knowledge of the national government's role in Greece's own unravelling makes it that much harder for a fair-minded person to muster hard feelings toward those imposing tough terms in exchange for volunteering rescue funds.

Additionally, while many countries are guilty of the sin of spending beyond their means, Greece is unique in that it took the additional step of wilfully conspiring to hide the true level of its debt through intentional book-cooking schemes. This history is fully apprehended by Greeks themselves and, therefore, again makes it harder for a rational and fair-minded individual (of which, granted, there is not always a large surplus when it comes to political opinion) to blame creditors for imposing tough terms when they agree to not only rescue another country, but one just caught cheating the rescuer in prior years.

All this said, some informants indicated that there was also public anger at both the Troika and at Germany for their handling of Greece's rescue. One individual noted that the Germans were perceived to be acting like 'colonialists', though another opined that Greeks always have needed to have an external 'enemy' - which used to be the United States but is now Germany and the IMF. Informants indicated that anti-European attitudes in Greece had grown over the last decade, and were informed by a mutual 'othering' process between Greece and Northern Europe which has driven the two apart. That said, others pointed to a broad and 'surprisingly steady support for the European project' by a 'mature' public - even in the face of perceptions of a predatory EU - noting that there is much less hostility to Europe than one might expect, in part because Greeks recognize their own complicity in the making of the crisis.

There are other mitigating factors in Greece as well, which likely serve to limit the degree to which the Crisis and the Troika's behaviour have diminished identification with Europe. It would probably be unfair to say that Greeks have, over the decades, been 'bought off' by the structural funds and other contributions that the EU has made to the country, but it would perhaps also be naive to assume that such largesse hasn't facilitated a certain degree of good will. This is especially likely considering the truly transformative nature of this assistance. Greece was a considerably poorer and less developed country before the EU came along, and the signs (literally signs, with the EU's flag on them) marking the Union's contributions to Greece's infrastructure 
and cultural (and therefore tourism revenue-generating) development are plastered all over the country. Interviews with respondents revealed that this fact is not lost on the Greeks. As one noted, 'decades of prosperity from EU membership' have created a strong and wide preference to remain in the EU and eurozone, and have contributed to a European identity in Greece that has come to join the national one in people's hearts and minds over the last 25 years.

Moreover, the Greeks take a certain degree of pride in being part - to seriously understate the contribution - of the Western tradition. This distinction may be amplified by the assistance it gives Greece in differentiating itself from its rival next door in Turkey. But even if that weren't the case, Greece can claim not only to be the incubus of Western democracy, but indeed of both respective ideas of the West and democracy themselves. Many informants made reference to the pride and European identity Greeks possess based on this history. It should not be surprising therefore that this identity has a certain degree of resilience in a culture with such a tradition.

Finally, it would be helpful to further understand developments in European identification within Greece if we could probe deeper inside the surveyed population to examine how different demographic and attitudinal cohorts have reacted to the Crisis. In fact, we can, although with a few frustrating exceptions. To do this, I divided the included surveys in this study into two groups, post-Crisis (the 2014 and 2015 surveys), and pre-Crisis (all the others) and then looked for any two surveys any one from each group - that included an identical question with identical (or very near) response choices. There were a number of useful survey items that met this criteria, but unfortunately also a few that might have been especially useful - social class and family financial condition, for example - where a question is asked after the Crisis but not before, or vice versa, making longitudinal analysis impossible. As it turned out, all matched-pair questions used Eurobarometer 84.3 (November 2015) as the source for 'post' data, and all but two used Eurobarometer 67.1 (February 2007) for the 'pre'. For each demographic or attitudinal indicator shown in Table 2, crosstabs were run against the same Format Four European identity measure discussed above. The penultimate column for each crosstab report simply presents a subtraction of the first survey's results from the second's, thus showing the amount of change over the time of the Crisis, and the last column expresses that same difference as a percentage gain or loss of the amount from the first survey of each pairing.

Table 2 includes the questions for which we have both before and after responses, and some of these are illuminating. First shown is education, which produces results one might expect. Broadly speaking, in both surveys, the more educated one is, the more likely that respondent is a European identifier. Moreover, the more educated one is the less likely identification is to have dropped (in two cases - 19 years of education and $22+$ years - it actually rises). These results are likely explained by the increased economic vulnerability to external forces of those at the end of the employment/SES dimension where lesser amounts of education are required. The education findings and the proposed explanation for them are also mostly echoed in the distribution of Greek European identifiers by occupation. Those in the most economically vulnerable occupations registered massive drops in their attachment to 
Table 2. Crosstabs of various measures against attachment to Europe. (Percent choosing 'Very' and 'Fairly Attached')

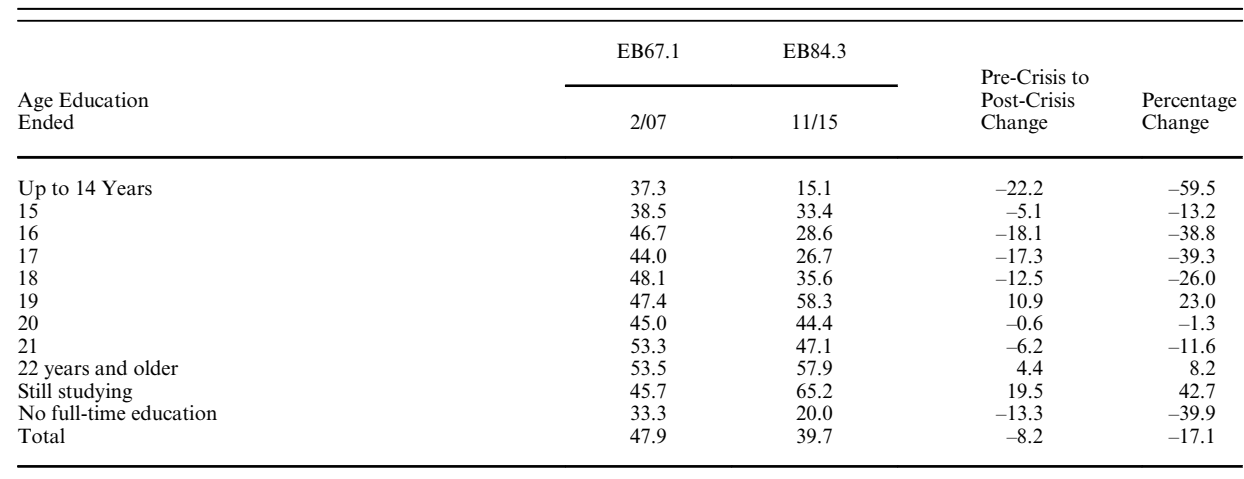

\begin{tabular}{|c|c|c|c|c|c|}
\hline \multirow[b]{2}{*}{ Occupation } & & EB67.1 & EB84.3 & \multirow[b]{2}{*}{$\begin{array}{l}\text { Pre-crisis to post-crisis } \\
\text { change }\end{array}$} & \multirow[b]{2}{*}{ Percentage chang } \\
\hline & & $2 / 07$ & $11 / 15$ & & \\
\hline $\begin{array}{l}\text { Responsible for Shopping, etc. } \\
\text { Student } \\
\text { Unemployed } \\
\text { Retired } \\
\text { Farmer } \\
\text { Fisherman } \\
\text { Professional } \\
\text { Owner of Shop, Craftsman } \\
\text { Business Proprietor } \\
\text { Employed Professional } \\
\text { General Management } \\
\text { Middle Management } \\
\text { Employed Position, At Desk } \\
\text { Employed Position, Traveling } \\
\text { Employed Position, Service Job } \\
\text { Supervisor } \\
\text { Skilled Manual Worker } \\
\text { Unskilled Manual Worker } \\
\text { Total } \\
N\end{array}$ & & $\begin{array}{r}49.4 \\
45.7 \\
31.8 \\
49.2 \\
36.4 \\
\\
54.6 \\
53.1 \\
33.3 \\
91.6 \\
100.0 \\
70.8 \\
49.0 \\
35.0 \\
35.1 \\
100.0 \\
46.9 \\
37.5 \\
48.3 \\
624\end{array}$ & $\begin{array}{r}19.3 \\
65.2 \\
34.9 \\
30.7 \\
35.3 \\
0.0 \\
72.8 \\
47.6 \\
40.0 \\
80.0 \\
100.0 \\
46.2 \\
60.6 \\
42.5 \\
50.0 \\
\\
50.0 \\
0.0 \\
39.8 \\
583\end{array}$ & $\begin{array}{r}-30.1 \\
19.5 \\
3.1 \\
-18.5 \\
-1.1 \\
\\
18.2 \\
-5.5 \\
6.7 \\
-11.6 \\
0.0 \\
-24.6 \\
11.6 \\
7.5 \\
14.9\end{array}$ & $\begin{array}{r}-60.9 \\
42.7 \\
9.7 \\
-37.6 \\
-3.0 \\
\\
33.3 \\
-10.4 \\
20.1 \\
-12.7 \\
0.0 \\
-34.7 \\
23.7 \\
21.4 \\
42.5 \\
\\
6.6 \\
-100.0 \\
-17.6\end{array}$ \\
\hline$N$ & EB67.1 & EB84.3 & & \multirow[b]{2}{*}{$\begin{array}{l}\text { Pre-crisis to post-crisis } \\
\text { change }\end{array}$} & \\
\hline Gender & $2 / 07$ & $11 / 15$ & & & Percentage change \\
\hline $\begin{array}{l}\text { Male } \\
\text { Female } \\
\text { Total } \\
N\end{array}$ & $\begin{array}{r}46.8 \\
49.0 \\
47.9 \\
624\end{array}$ & $\begin{array}{c}45.4 \\
34.6 \\
39.8 \\
583\end{array}$ & & $\begin{array}{r}-1.4 \\
-14.4 \\
-8.1\end{array}$ & $\begin{array}{r}-3.0 \\
-29.4 \\
-16.9\end{array}$ \\
\hline & EB67.1 & EB84.3 & & \multirow[b]{2}{*}{$\begin{array}{l}\text { Pre-crisis to } \\
\text { post-crisis change }\end{array}$} & \multirow[b]{2}{*}{$\begin{array}{l}\text { Percentage } \\
\text { change }\end{array}$} \\
\hline Age Group & $2 / 07$ & $11 / 15$ & & & \\
\hline $\begin{array}{l}15-24 \\
25-34 \\
35-44 \\
45-54 \\
55-64 \\
65 \text { and older } \\
\text { Total } \\
N\end{array}$ & $\begin{array}{l}41.4 \\
51.0 \\
50.9 \\
48.4 \\
56.4 \\
42.0 \\
47.9 \\
626\end{array}$ & \begin{tabular}{r|}
55.7 \\
48.2 \\
47.8 \\
42.3 \\
34.6 \\
25.1 \\
39.8 \\
587
\end{tabular} & & $\begin{array}{r}14.3 \\
-2.8 \\
-3.1 \\
-6.1 \\
-21.8 \\
-16.9 \\
-8.1\end{array}$ & $\begin{array}{r}34.5 \\
-5.5 \\
-6.1 \\
-12.6 \\
-38.7 \\
-40.2 \\
-16.9\end{array}$ \\
\hline
\end{tabular}


Table 2: (Continued)

\begin{tabular}{|c|c|c|c|c|}
\hline & EB67.1 & EB84.3 & \multirow[b]{2}{*}{$\begin{array}{c}\text { Pre-crisis to post-crisis } \\
\text { change }\end{array}$} & \multirow[b]{2}{*}{ Percentage change } \\
\hline Type of community & $2 / 07$ & $11 / 15$ & & \\
\hline $\begin{array}{l}\text { Rural Area or Village } \\
\text { Small / Middle-sized Town } \\
\text { Large Town } \\
\text { Total } \\
N\end{array}$ & $\begin{array}{l}43.1 \\
37.6 \\
53.7 \\
47.8 \\
625\end{array}$ & $\begin{array}{l}35.1 \\
37.4 \\
42.1 \\
39.7 \\
585\end{array}$ & $\begin{array}{r}-8.0 \\
-0.2 \\
-11.6 \\
-8.1\end{array}$ & $\begin{array}{r}-18.6 \\
-0.5 \\
-21.6 \\
-16.9\end{array}$ \\
\hline Marital Status & EB67.1 & EB84.3 & $\begin{array}{l}\text { Pre-crisis to } \\
\text { post-crisis } \\
\text { change }\end{array}$ & $\begin{array}{l}\text { Percentage } \\
\text { change }\end{array}$ \\
\hline $\begin{array}{l}\text { Married } \\
\text { Remarried } \\
\text { Married / Remarried } \\
\text { Living With Partner } \\
\text { Never Lived With Partner } \\
\text { Previously Lived With Partner } \\
\text { Single } \\
\text { Divorced } \\
\text { Separated } \\
\text { Divorced / Separated } \\
\text { Widowed } \\
\text { Total } \\
N\end{array}$ & $\begin{array}{r}51.6 \\
100.0 \\
\\
62.5 \\
40.5 \\
46.2 \\
\\
64.0 \\
43.1 \\
\\
30.8 \\
48.0 \\
622\end{array}$ & $\begin{array}{c}36.8 \\
28.8 \\
39.8 \\
586\end{array}$ & $\begin{array}{l}-2.0 \\
-8.2\end{array}$ & $\begin{array}{r}-6.5 \\
-17.1\end{array}$ \\
\hline & EB67.1 & EB84.3 & \multirow[b]{2}{*}{$\begin{array}{l}\text { Pre-crisis to post-crisis } \\
\text { change }\end{array}$} & \multirow[b]{2}{*}{ Percentage change } \\
\hline $\begin{array}{l}\text { Left-Right } \\
\text { Placement (1-10) }\end{array}$ & $2 / 07$ & $11 / 15$ & & \\
\hline $\begin{array}{l}1-2 \text { (Left) } \\
3-4 \\
5-6 \\
7-8 \\
9-10 \text { (Right) } \\
\text { Total } \\
N\end{array}$ & $\begin{array}{c}57.5 \\
45.6 \\
47.3 \\
52.1 \\
53.8 \\
49.7 \\
461\end{array}$ & $\begin{array}{c}26.4 \\
39.2 \\
44.9 \\
37.5 \\
31.8 \\
39.6 \\
586\end{array}$ & $\begin{array}{r}-31.1 \\
-6.4 \\
-2.4 \\
-14.6 \\
-22.0 \\
-10.1\end{array}$ & $\begin{array}{r}-54.1 \\
-14.0 \\
-5.1 \\
-28.0 \\
-40.9 \\
-20.3\end{array}$ \\
\hline & EB65.2 & EB84.3 & \multirow{2}{*}{$\begin{array}{l}\text { Pre-crisis to post-crisis } \\
\text { change }\end{array}$} & \multirow[b]{2}{*}{ Percentage change } \\
\hline Life Satisfaction & $3 / 06$ & $11 / 15$ & & \\
\hline $\begin{array}{l}\text { Very Satisfied } \\
\text { Fairly Satisfied } \\
\text { Not Very Satisfied } \\
\text { Not At All Satisfied } \\
\text { Total } \\
N\end{array}$ & $\begin{array}{c}54.2 \\
47.1 \\
29.9 \\
40.0 \\
43.3 \\
279\end{array}$ & $\begin{array}{r}58.9 \\
53.3 \\
38.8 \\
20.0 \\
39.7 \\
584\end{array}$ & $\begin{array}{r}4.7 \\
6.2 \\
8.9 \\
-20.0 \\
-3.6\end{array}$ & $\begin{array}{r}8.7 \\
13.2 \\
29.8 \\
-50.0 \\
-8.3\end{array}$ \\
\hline$N$ & EB65.2 & EB84.3 & \multirow{2}{*}{$\begin{array}{l}\text { Pre-crisis to post-crisis } \\
\text { change }\end{array}$} & \multirow[b]{2}{*}{ Percentage change } \\
\hline Situation: National Economy & $3 / 06$ & $11 / 15$ & & \\
\hline $\begin{array}{l}\text { Very Good } \\
\text { Rather Good } \\
\text { Rather Bad } \\
\text { Very Bad } \\
\text { Total } \\
N\end{array}$ & $\begin{array}{l}50.0 \\
68.8 \\
51.8 \\
24.6 \\
43.4 \\
279\end{array}$ & $\begin{array}{c}75.0 \\
46.2 \\
50.9 \\
36.4 \\
39.7 \\
585\end{array}$ & $\begin{array}{r}25.0 \\
-22.6 \\
-0.9 \\
11.8 \\
-3.7\end{array}$ & $\begin{array}{r}50.0 \\
-32.8 \\
-1.7 \\
48.0 \\
-8.5\end{array}$ \\
\hline
\end{tabular}


Europe from 2007 to 2015, including homemakers (61\% loss) and retirees ( $38 \%$ loss). However, those listed as 'middle management' also had a major drop (35\%) as did, to a lesser extent, 'employed professionals' (13\%), while at the same time, 'professionals' grew in levels of European identification (33\%), as did students (43\%) and the three categories of 'employed positions' (24, 21 and 43\% gains). That some of these results are unexpected and even a bit erratic may have to do with small sample sizes in each cell (there were about 600 Greek respondents to each survey, spread over about 17 categories). In any case, these findings were echoed by many of the informants who provided the qualitative data for this study, several of whom noted their perception of a positive correlation between education and SES status, on the one hand, and proEuropean attitudes on the other.

Further evidence that European identification in Greece fell disproportionately among those who are more economically vulnerable comes from an examination of the gender and age crosstabs in Table 2. Women shed their sense of attachment to Europe by almost a third of the total cohort (a 29\% loss), while men remained almost unchanged. At the same time, there is a secular trend for age categories, such that the older one is, the more likely one is to have lost their European identity, especially for those over age 55 , for whom approximately $40 \%$ of those who possessed an attachment to Europe in 2007 had given it up by 2015.

The breakout data for type of community present a somewhat puzzling pattern, with losses in European identifiers over time in both rural areas and large towns, but more or less no change in medium-size communities in-between. To some degree, this may be reflective of ideological patterns (see below). Tendencies according to marital status are also difficult to interpret, but in this case it is because of the inconsistent categorization of responses used in the before and after Eurobarometer surveys.

The distribution of Greek respondents according to ideology is just as one might predict. Europeans of the left and right have long tended to dislike and distrust the integration project - the former for the EU's perceived neoliberal economic tendencies, and the latter because of the loss of national sovereignty entailed. Certainly the Troika versus Greece scenario provided ample fodder for both concerns, and Table 2 shows that pre- versus post-Crisis losses in European identification among Greeks increase dramatically, moving outward from the ideological centre (although, interestingly, the Greece of 2007 starts off with somewhat more identifiers on the left and right than in the centre).

The attitudinal measure of 'life satisfaction' also produces a revealing juxtaposition with European identification patterns. Greece experienced a massive increase from 2006 to 2015 in the proportion of respondents indicating they were 'not at all satisfied' with their lives (these figures are not shown in Table 2). In the earlier year, only a little over $7 \%$ of respondents gave that answer. By 2015 , well over $27 \%$ put themselves in that category. And, whereas Table 2 reveals that for all Greeks identification with Europe had by 2015 fallen about $8 \%$ off of the 2006 level, for the subset who were 'not at all satisfied' with their lives, fully half the proportion who had previously felt attached to Europe stopped feeling that way in the post-Crisis 
measure. This is highly supportive of the instrumentalist notion that there is some blame imputed to the Troika/Europe in the minds of many Greeks for the unfortunate turn in their personal circumstances, and that this perception affects identity.

Finally, the data in Table 2 with regard to perceptions of the national economy are a bit confusing at first glance. The erraticism of moving from a 50\% gain in European identification among the proportion who believe the Greek economy to be 'very good' versus a nearly 33\% drop for those who see it as 'rather good' can be explained by the fact (not shown in Table 2) that almost nobody populates these particular cells in the crosstabs. In both the 2006 and 2015 surveys, almost everyone thought the national economy in Greece was either 'rather bad' or 'very bad' (a total of $87 \%$ of respondents in 2006 and $97 \%$ in 2015). The real change was between these two unhappy categories. In 2006, 49\% saw the economy as 'rather bad', whereas in 2015, only $19 \%$ did. That's because the missing balance had moved to the 'very bad' category, which more than doubled, from $38 \%$ of respondents to $78 \%$. In terms of European identification patterns, we see almost no change among those in the "rather bad' category, but a drop of nearly half from 2006 to 2015 among those seeing the economy as 'very bad'. This once again suggests a causal link in the minds of Greeks between their country's economic fortunes and the actions of European institutions, and also suggests, per the instrumentalist approach to identity, substantial negative consequences of that relationship in terms of the tendency of Greeks to identify as European.

\section{Conclusion}

Theorists have suggested that mass political identities can be driven by a transactional dynamic, in which the public becomes attached to a people, polity or culture in exchange for something, especially of a material nature, in return. The particular experience of Greece in the last decade has permitted us to test the validity of such an instrumental approach to the phenomenon of European identification.

European integration (what we might call 'supra-state-building') is still a relatively young project, compared with, say, the polities of France or England. It has also developed in a place and time where a nasty recent experience has created an unsurprising reticence about the concept of embracing powerful emotional identities of any sort. And it seeks to integrate often culturally very different member-states most of which with existing national identities - around a rather remote, opaque and poorly-understood institutional core. None of these factors, nor others that could be listed, bode well for the development of a sustained - and sustaining - European identity. Previous research has shown that such an identity does exist, but that it does not have many strong adherents, and its power is diminished by the fact that its character is far more cerebral than emotional in nature.

Nevertheless, until the last decade, European integration has been blessed with the most fortuitive of circumstances in which to be born and develop. The post-war years far exceed any time in history for a prolonged period of peace and prosperity in Europe. But, some scholars have wondered, what would happen to the project when 
and if the ill winds of fortune blew across the continent instead. And, in particular, what would happen if there was little of an established European identity filling the requisite 'reservoir upon which a system typically draws in times of crises' that Easton and Dennis sagely posited decades ago.

Regrettably for many, Europe seems to be testing this axiom in the current moment, and the signs do not seem propitious. Although the European integration process has proceeded in fits and starts and lurched from crisis to recovery from its very beginning, few episodes in that history seem as fraught as the current moment from the perspective of those who favour the project. Britain is now exiting (the first country ever to do so), there has been much talk of Greece leaving - either voluntarily or being tossed out - the economy is chronically stagnant and underperforming in many places, domestic support for integration is weak all over while nationalist parties are stronger than ever, and member-state has been pitted against memberstate in struggles over scarce resources.

It doesn't require fancy academic theory to recognize that this is not a prescription for success, especially when it is occurring over the absence of a strong identity foundation. France, qua France, may well be able to survive even multiple catastrophes without ceasing to exist - because of the core of French identity sustaining it - but the same hardly seems likely of the European Union, at least in 2018.

The current study suggests that such vulnerability is palpable in the current moment. The case of Greece provides evidence for the instrumentalist notion that diminished material benefits stemming from a relationship will lead to diminished levels of identification. In those member-states that got what they wanted (austerity policy) from Europe, European identity rose over the decade of crisis. In those - like Greece - where policies perceived by many as harsh and punitive were imposed upon them, attachment to Europe fell, and it fell especially hardest among those most vulnerable to economic conditions.

These findings are of interest to scholars seeking to understand the mechanics of one of the more recondite of human behaviour sets, political identity. But they may also be of interest to those who see the European experiment of the last half-century as valuable and worth preserving. Not everyone does, of course, and there are many in Europe who despise the concept. But for those who wish to preserve the European state, the necessity of undergirding it with a viable European nation seems clearer now than ever, as does the requirement of including tangible benefits among the elements necessary to attract individuals to such an identity.

\section{Acknowledgements}

The author is deeply grateful to all those who were kind enough to give their time in interviews for this project, as well as to those who were so helpful in making introductions to assist in arranging those interviews. 


\section{References}

1. J. Rothschild (1981) Ethnopolitics: A Conceptual Framework (New York: Columbia University Press).

2. C.H. Enloe (1973) Ethnic Conflict and Political Development (Boston: Little, Brown and Company).

3. C. Young (1976) The Politics of Cultural Pluralism (Madison: University of Wisconsin Press).

4. N. Kasfir (1975) The Shrinking Political Arena: Participation and Ethnicity in African Politics, with a Case Study of Uganda (Berkeley: University of California Press).

5. R. Melson and H. Wolpe (Eds) (1971) Nigeria: Modernization and the Politics of Communalism (East Lansing: Michigan State University Press).

6. N. Glazer and D.P. Moynihan (Eds) (1975) Ethnicity: Theory and Experience (Cambridge: Harvard University Press).

7. S. Olzak and J. Nagel (Eds) (1986) Competitive Ethnic Relations (Orlando: Academic Press).

8. D. Bell (1975) Ethnicity and social change. In N. Glazer and D.P. Moynihan (Eds), Ethnicity: Theory and Experience (Cambridge, MA: Harvard University Press), pp. 141-174.

9. J. Saul (1979) State and Revolution in Eastern Africa (New York: Monthly Review Press).

10. O. Nnoli (1978) Ethnic Politics in Nigeria (Enugu: Fourth Dimension Publishing Company).

11. R.H. Bates (1983) Modernization, ethnic competition and the rationality of politics in contemporary Africa. In D. Rothschild and V. Olorunsola (Eds), State Versus Ethnic Claims: African Policy Dilemmas (Boulder, CO: Westview Press), pp. 152-171.

12. A. Rabushka and K.A. Shepsle (1972) Politics in Plural Societies: A Theory of Political Instability (Columbus: Charles E. Merrill Publishing Company).

13. M. Hechter (1986) Rational choice theory and the study of race and ethnic relations. In: J. Rex and D. Mason (Eds), Theories of Ethnic and Race Relations (Cambridge: Cambridge University Press), pp. 264-279.

14. C. Young (1993) The dialectics of cultural pluralism: Concept and reality. In C. Young (Ed.), The Rising Tide of Cultural Pluralism: The Nation-State At Bay? (Madison: University of Wisconsin Press), p. 22.

15. R. Cohen (2015) The migrant crisis in Calais exposes a Europe without ideas. New York Times, 3 August. http://www.nytimes.com/2015/08/04/opinion/rogercohen-the-migrant-crisis-in-calais-exposes-a-europe-without-ideas.html?_r=0 (accessed 31 July 2016).

16. D. Easton and J. Dennis (1969) Children in the Political System: Origins of Political Legitimacy (New York: McGraw-Hill), p. 63.

17. R. Inglehart (1977) The Silent Revolution: Changing Values and Political Styles among Western Publics (Princeton, NJ: Princeton University Press), pp. 329-332, 356-357.

18. S. Duchesne and A-P. Frognier (1995) Is there a European identity?. In O. Niedermayer and R. Sinnott (Eds), Public Opinion and Internationalized Governance (Oxford: Oxford University Press), pp. 193-226.

19. D.M. Green (2007) The Europeans: Political Identity in an Emerging Polity (Boulder, CO: Lynne Rienner Publishers).

20. K. Schilde (2014) Who are the Europeans? European identity outside of European integration. Journal of Common Market Studies, 52(3), pp. 650-667. 
21. O. Agirdag, P. Huyst and M. Van Houtte (2012) Determinants of the formation of a European identity among children: Individual- and school-level influences. Journal of Common Market Studies, 50(2), pp. 198-213.

22. E. Quintelier, S. Verhaegen and M. Hooghe (2014) The intergenerational transmission of European identity: The role of gender and discussion within families. Journal of Common Market Studies, 52(5), pp. 1103-1119.

23. N. Fligstein, A. Polyakova and W. Sandholtz (2012) European integration, nationalism and European identity. Journal of Common Market Studies, 50(S1), pp. 106-122.

24. K. Mitchell (2015) Rethinking the 'Erasmus Effect' on European identity. Journal of Common Market Studies, 53(2), pp. 330-348.

25. C. Gnutzmann, J. Jakisch and F. Rabe (2014) English as a Lingua Franca: A source of identity for young Europeans? Multilingua, 33(3-4), pp. 437-457.

26. J. Roose (2013) How European is European identification? Comparing continental identification in Europe and beyond. Journal of Common Market Studies, 51(2), pp. 281-297.

27. D.M. Green (2012) Are Europeans made in America? Identity, alterity and the United States as Europe's 'other'. Journal of Transatlantic Studies, 10(1), pp. 125.

28. L. Cram (2009) Identity and European integration: Diversity as a source of integration. Nations and Nationalism, 15(1), pp. 109-128.

29. M. Hadler, K. Tsutsui and L.G. Chin (2012) Conflicting and reinforcing identities in expanding Europe: Individual- and country-level factors shaping national and European identities, 1995-2003. Sociological Forum, 27(2), pp. 392-418.

30. T. Risse (2014) No demos? Identities and public spheres in the Euro crisis. Journal of Common Market Studies, 52(6), pp. 1207-1215.

31. D. Chalániová (2013) Turn the other Greek: How the Eurozone crisis changes the image of Greeks and what visual representations of Greeks tell us about European identity. Perspectives, 21(1), pp. 5-41.

32. A. Visvizi (2014) From Grexit to Grecovery: The paradox of the Troika's engagement with Greece. Perspectives on European Politics and Society, 15(3), pp. 325-345.

33. Eurobarometer, Various Authors. Eurobarometer Numbers 36.0, 51.0, 54.1, 58.1, 60.1, 62.0, 63.4, 65.2, 67.1, 67.2, 68.1, 73.3, 79.5, 80.1, 82.3 and 84.3. ICPSR Version. 1991-2015 (Ann Arbor, MI: Institute for Social Research [producer], Inter-university Consortium for Political and Social Research [distributor]).

34. International Social Survey Program (ISSP). International Social Survey Program: National Identity, 1995 and 2003 [Computer file]. ICPSR release (Koeln, Germany: Zentralarchiv fuer Empirische Sozialforschung [producer], 2003. Koeln, Germany: Zentralarchiv fuer Empirische Sozialforschung/Ann Arbor, MI: Inter-university Consortium for Political and Social Research [distributors]).

\section{About the Author}

David Green is Professor of Political Science at Hofstra University in New York. He is the author of a book, multiple articles and a chapter in an edited volume, all on the topic of European identity. He has also published scholarly articles on various other aspects of international relations, international organization and political theory. 